\title{
Yhteiskuntaluokka elää ja voi paremmin kuin hyvin äänestämisen vedenjakajana, keskeinen jakolinja siirtynyt äänestyskopin sisältä äänestyspaikan kynnykselle
}

HANNU LAHTINEN ${ }^{1}$

Sosioekonomisen aseman merkitys siinä, kuinka todennäköisesti ihminen äänestää, on klassinen teema useilla yhteiskuntatieteen aloilla. Jo vuonna 1937 Herbert Tingsten teki katsauksen väestöryhmien äänestyskäyttäytymistä vaaleissa käsittelevistä tilastollisista tutkimuksista. Hänen päätuloksensa oli: "Yleisenä sääntönä poliittinen kiinnostus kasvaa, mitä korkeammalle sosiaalinen asema yltää" (Tingsten 1937, 230: käännös kirjoittajan). Tästä lähtien Tingstenin sääntö on havaittu yhä uudelleen yhdeksi pitävimmistä säännönmukaisuuksista ja kestävimmistä ongelmista vaalitutkimuksessa.

Suomessa yhteiskuntaluokan ja äänestämistodennäköisyyden välisen yhteyden vahvisti empiirisesti Erik Allardt Kettil Bruunin kanssa 50-luvun puolivälissä (Allardt ja Bruun 1956). Vuosikymmen myöhemmin Tuomo Martikaisen johtama projekti uursi menetelmällisiä uria keräämällä neljän prosentin otoksen äänioikeutettujen äänestämässä käymisestä 1968 kuntavaalien äänestyslistoista (Martikainen ja Sänkiaho 1969). Tämä tieto voitiin yhdistää joihinkin demografisiin taustatietoihin: ikään, sukupuoleen ja äidinkieleen - ja parhaan tietämykseni mukaan aloitti äänestysaktiivisuuden yksilötason rekisteritutkimuksen. Ehkäpä vieläkin enemmän tutkimuskenttää mullistettiin vuoden 1987 vaaleissa, joista jokainen ääni kerättiin käsin paperilistoilta, ja näin tieto äänestämässä käymisestä voitiin yhdistää tyypilliset sosiodemografiset taustatekijät sisältäviin rekistereihin koko väestöltä (Martikainen ja Yrjönen 1991). Tuo aineisto oli suorastaan hämmentävän paljon aikaansa edellä: lähinnä Pohjoismaissa on saatavilla yksilötason rekisteriaineistoja äänestämässä käymisestä, ja nekin vain noin viimeisen kymmenen vuoden ajalta.

Olen tähänastisessa esityksessäni maininnut kolme elementtiä: äänestysosallistumisen, rekisteriaineistot ja sosioekonomisen aseman. Jälkimmäinen on puolestaan ihmisen paikkaa yhteiskunnan, varsinkin taloudellisen järjestelmän, hierarkiassa kuvaava käsite, jota olen mitannut koulutuksen, ammattiasemaan perustuvan yhteiskuntaluokan ja tulojen avulla. Yhdessä nämä komponentit muodostavat perustuksen, jonka varaan olen rakentanut väitöstutkimukseni (Lahtinen 2019).

Yhteiskuntaluokkaan liittyviin akateemisiin keskusteluihin on liittynyt jo pitkään yleinen narratiivi, jonka mukaan luokan merkitys oli suuri aikoinaan, mutta on nyt ajan myötä väistymässä. Keskustelu yhteiskuntaluokan merkityksestä politiikan kentillä on suorastaan malliesimerkki edellisestä. Ja todella näyttääkin siltä, että yhteiskuntaluokan ennustekyky siinä, mitä äänestyskuponkiin kirjoittaa, on vähentynyt vuosikymmenten kuluessa (Jansen ym. 2013). Artikkelini aiheena ei kuitenkaan ole puolue- tai ehdokasvalinta, joten tässä yhteydessä en syvenny näihin sen tarkemmin. Professori Geoffrey Evansin erinomaista työtä näiden kehityskulkujen 
dokumentoimisessa ja vakuuttavassa selittämisessä (esim. Evans ja Tilley 2017) voi kuitenkin varauksetta suositella.

Kysymys siitä erotteleeko sosioekonominen asema äänestysvalintaa, on kuitenkin mielekäs vain silloin, jos ihmiset ylipäätään käyvät äänestämässä. Äänestysaktiivisuus lieneekin siten äänestysvalintaa perustavanlaatuisempi äänestämisen ulottuvuus. Sosioekonominen asema voi olla äänestysaktiivisuudessa erottelevampi tekijä tämän hetken Suomessa, kuin kenties koskaan aiemmin yleisen ja yhtäläisen äänioikeuden aikakaudella - vaikka vertailukelpoista aineistoa joka vaaleista ei tietenkään ole. Yhteiskuntaluokan painopiste äänestämisen vedenjakajana siis on siirtynyt maantieteellisesti äänestyskopista yhä vahvemmin äänestyspaikan kynnykselle. Väitöskirjani ensimmäisen kuvio havainnollistaa koulutuksen merkityksen kasvua:

Kuvio 1. Äänestysaktiivisuus iän ja koulutuksen mukaan 1987, 1999 ja 2015 eduskuntavaaleissa, \%.

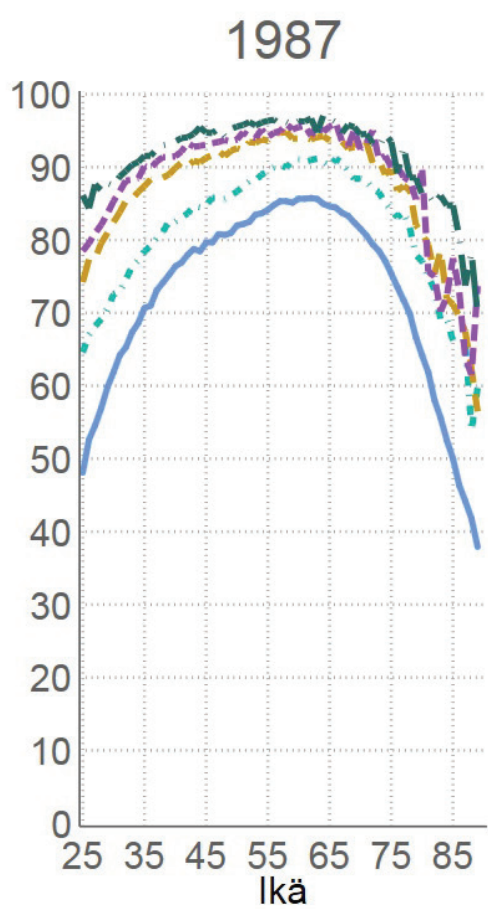

- Perusaste

-n=- Alempi korkea-aste
1999

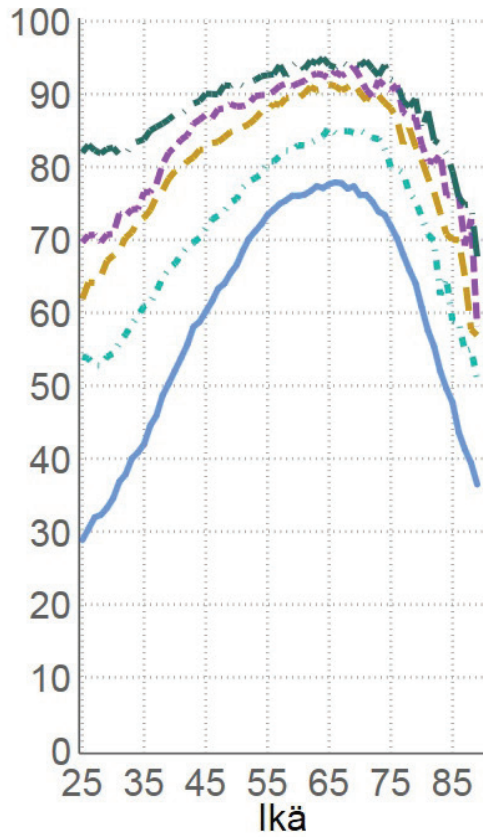

Keskiaste
2015

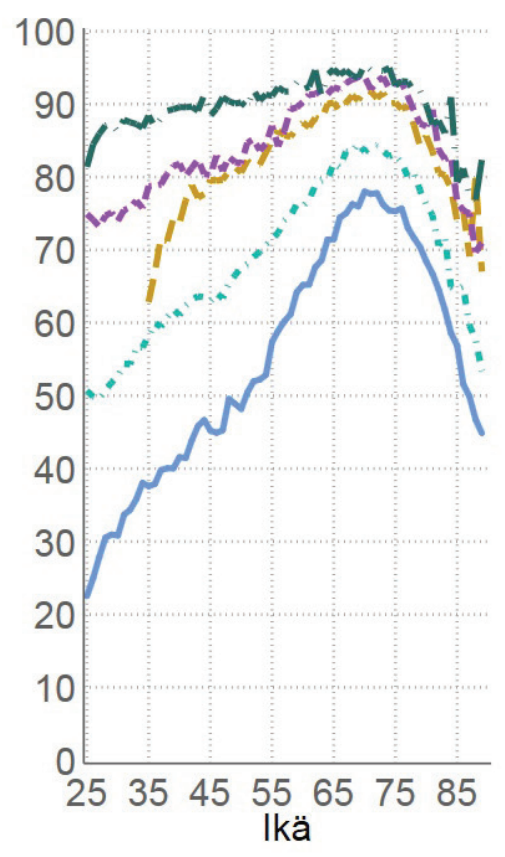

$=--$ Alin korkea-aste

Lahtinen 2019, 40 (kuvio 1: käännös tekijän)

Kuviossa 1 näemme äänestysaktiivisuuden iän ja koulutuksen mukaan kolmissa eduskuntavaaleissa. Vuonna 1987 kaikkien Suomessa asuvien suomalaisten äänestysaktiivisuus oli 74 prosenttia. Kuvion vasemmassa sarakkeessa näkyy koulutusryhmittäinen hierarkia kyseisissä vaaleissa kaikissa ikäryhmissä, joskin korkea-asteen tutkinnon suorittaneiden keskuudessa erot olivat 
varsin pienet. Keskimmäinen sarake näyttää tilanteen 12 vuoden jälkeen vuonna 1999, jolloin kaikkien Suomessa asuvien äänestysaktiivisuus oli pudonnut 68 prosenttiin. Yleisen aktiivisuuden laskun ohella oli tapahtunut selvä koulutusryhmittäinen eriytyminen varsinkin nuoremmissa ikäryhmissä. Vuonna 2015 äänestysaktiivisuus oli hieman korkeampi, 70 prosenttia. Siitä huolimatta äänestysaktiivisuuden koulutusryhmittäinen polarisaatio on jatkunut.

Erojen suuruus ja trendin vahvuus ovat huomattavia käytännössä millä tahansa yhteiskuntatieteellisellä mittapuulla arvioituna. Äänestysaktiivisuuskäyrän muoto vain perusasteen tutkinnon suorittaneilla muistuttaa sulavaa jäävuorta. Huippu, jossain 70 ikävuoden tienoilla, on lähes yhtä korkea kuin aiemmin, mutta on kaventunut kovin ohueksi. Yhtä kiinnostavaa on se, että korkeasti koulutettujen nuorten aikuisten äänestysaktiivisuus on kasvanut vuosituhannen vaihteesta. Yleinen koulutusmahdollisuuksien laajentuminen ja koulutustason kasvu on tehnyt vain peruskoulun varassa olevista aiempaa pienemmän ja oletettavasti negatiivisesti valikoituneemman joukon. Toisaalta saman kehityskulun seurauksena korkeasti koulutetut ovat entistä vähemmän positiivisesti valikoitunut joukko. Havainto siis tuskin selitty pelkällä väestötason valikoitumisella, vaan taustalla on muitakin vaikuttavia tekijöitä.

Tällainen suuri äänestysaktiivisuuden eriytyminen kyseenalaistaa sitä, kuinka hyvin kansanedustajat - tehtävänimikkeensä mukaisesti - edustavat kansaa. Lisäksi äänestämistä voi pitää myös laajempana sosiaalisena indikaattorina. Tästä näkökulmasta joidenkin väestöryhmien yhteiskunnallisessa integraatiossa näyttää olevan ongelmia. Nämä ryhmät ovat enenevässä määrin vieraantumassa ainakin virallisesta poliittisesta järjestelmästä. Mikä vielä polttavampaa, tässä tutkimuksessa nämä "jotkin väestöryhmät" eivät ole mitä tahansa väestön osajoukkoja, vaan ne määrittyvät yleisesti käytettyjen yhteiskunnallisen eriarvoisuuden jakolinjojen mukaan (esim. Galobardes ym. 2006a; 2006b). Havainnot viittaavat toimintahäiriöihin paitsi institutionaalisessa poliittisessa järjestelmässä, mutta myös kansalaisyhteiskunnassa laajemmin. Mitä sellaista on tapahtunut suomalaisessa yhteiskunnassa viimeisten vuosikymmenien aikana, joka on tuottanut näin dramaattisen erkanemisen? Kysymykseen vastaaminen on erittäin tärkeä jatkohaaste meille yhteiskuntatieteilijöille.

Lisäksi esitän väitöskirjassani, että sosioekonomiset erot äänestysaktiivisuudessa ovat polttavampi yhteiskunnallinen ongelma, kuin mitä aiempi tutkimuskirjallisuus on antanut ymmärtää. Kuten jo mainittua, lukuni ovat virallisesta äänioikeusrekisteristä. Ihmiset voivat huijata, mutta rekisteri ei (toki tietyin kohtuullisin oletuksin). Väitöskirjani ensimmäisen osa-artikkelin (Lahtinen ym. 2019a) tulokset viittaavat siihen, että tunnetut mittausvirheet äänestysaktiivisuuteen liittyvissä kyselyissä - vastaajien valikoituminen ja sosiaalisesta suotavuudesta aiheutuva yliraportointi - johtavat äänestysaktiivisuuden sosioekonomisten erojen aliarviointiin. Osittain näistä syistä jopa alan tukijat ovat aliarvioineet kyseisten erojen merkitystä. Niitä, jotka ovat kiinnostuneet sosioekonomisten erojen aliarvostuksesta spekulatiivisemmista syistä, suosittelen tutustumaan väitöskirjani yhteenvedon päätösosioon (Lahtinen 2019, 55-58).

Normatiiviselta kannalta äänestämässä käyminen muodostaa mielenkiintoisen tapauksen. Ainakin periaatteessa jokaisella kansalaisella on yhtäläinen oikeus äänestää - ja kolikon toisena puolena yhtäläinen oikeus jättää äänestämättä. Onko siis paikallaan puhua sosioekonomisesta eriytymisestä eriarvoisuutena? Väitöskirjassani eriarvoisuus-sanaa on yleensä (joskaan ei aina) vältetty. Sen sijaan keskustelen useimmiten yksinkertaisesti sosioekonomisista eroista. Sanavalintani oli kuitenkin varsin konservatiivinen. Sitä havainnollistaa erityisen hyvin 
äänestysaktiivisuuden voimakas ylisukupolvinen siirtymä, joka tutkimuksessani myös havaittiin. Kolmas osatutkimus (Lahtinen ym. 2019b) sekä väitöskirjani yhteenveto-osan taulukko 3 [tässä tekstissä taulukko 1] havainnollistavat tätä. Taulukko esittää nuorten aikuisten äänestysaktiivisuuden 2015 eduskuntavaaleissa heidän vanhempiensa koulutuksen mukaan. Vähemmän sosiologisesti oppinut yleisö voisi kyseenalaistaa tällaisen analyysin mielekkyyden: mikä järki on ryhmitellä yhden ihmisen äänestämistä kokonaan toisen ihmisen koulutuksen mukaan? Taulukon tulokset puhuvat kuitenkin puolestaan. Niistä nuorista aikuisista, joiden molemmilla vanhemmilla oli vain perusasteen tutkinto, äänesti vain 28 prosenttia, kun taas niiden kohdalla, joilla ainakin toisella vanhemmista on maisteritason tutkinto, 69 prosenttia. Nämä ovat jälleen dramaattisia eroja. Kaikki eivät lähde tähän peliin samalta viivalta (vrt. Verba ym. 2003).

Taulukko 1. 18-24-vuotiatiden äänestysaktiivisuus eduskuntavaaleissa 2015 korkeammin koulutetun vanhemman koulutuksen mukaan

\begin{tabular}{ll} 
Vanhemman koulutustaso & $\%$ \\
\hline Perusaste & 28.0 \\
Toinen aste & 38.7 \\
Alin korkea-aste & 51.0 \\
Alempi korkea-aste & 58.6 \\
Ylempi korkea-aste & 69.3 \\
\hline Kaikki & $\mathbf{4 7 . 2}$
\end{tabular}

Lahtinen 2019, 42 (taulukko 3: käännös tekijän)

Esitän vielä yhden ajatuksen. Haluaisin alleviivata - ehkä hivenen idealistisesti - että äänestysaktiivisuuden eriarvoisuuden pitäisi olla päivänpoliittiset väännöt ylittävä asia. Kirjoittaessani ja kansantajuistaessani väitöskirjaa suurelle yleisölle olen tietoisesti yrittänyt välttää puoluepolitisoimasta tätä ongelmaa. Esimerkiksi olen kieltäytynyt esittämästä arvioita siitä, miten puolueet hyötyisivät sosioekonomisten erojen kaventamisesta. Valtiomiesmäinen suurten linjojen hahmotus on asiassa tarpeen.

Tasa-arvoinen osallistuminen on tärkeää koko edustuksellisen demokratian legitimiteetin ja toimintakyvyn kannalta. Lopulta jokaiselle puolueelle on eduksi, mikäli erot äänestämisessä ja äänestämättä jättämisessä kapenisivat. Voltairen väitetään (luultavasti virheellisesti) sanoneen seuraavaa: "En hyväksy mielipidettänne, mutta tulen kuolemaani saakka puolustamaan teidän oikeuttanne ilmaista se."

Äänestämisessä jos jossakin Voltairen lentävän lauseen periaatetta soisi noudatettavan. On kieltämättä houkuttelevaa ajatella, että niiden, joiden mielipidettä emme hyväksy, soisi mieluummin jättävän äänestämättä. Kuitenkin niin kauan kuin ihmiset äänestävät, on toivoa. Erik Allardtin pelikirjasta (vrt. Alapuro 1997) voidaan johtaa oppi, jonka mukaan myös protestipuheenvuorot voidaan integroida yhteiskuntaan, kun niille annetaan asiaankuuluva mahdollisuus 
ja vastuu. Vaalit voivat olla myös väylä joidenkin syrjäytymisvaarassa olevien integraatioon, ainakin omalta pieneltä osaltaan. "Väärin” äänestävien sijaan meidän olisi syytä olla paljon enemmän huolissamme pitkittyneestä, jopa sukupolvien yli kestävästä poliittisesta syrjäytymisestä. Se, jos jokin, tuottaa hedelmällistä maaperää monen tyyppiselle ekstremismille.

\section{VIITTEET}

1. Kirjoitus perustuu 27.9.2019 Helsingin yliopistossa järjestetyn väitöstilaisuuden lectio praecursoria -esitelmään.

\section{LÄHTEET}

Alapuro, Risto. 1997. Ylioppilasliike ja sosiologia 60-luvulla - eli miten sosiologia auttoi opiskelijoita löytämään kansandemokraattisen liikkeen. Tieteessä tapahtuu 15:4, 7-10.

Allardt, Erik ja Bruun, Kettil. 1956. Characteristics of the Finnish non-voter. Transactions of the Westermarck Society 3, 56-76.

Evans, Geoffrey ja Tilley, James. 2017. The new politics of class: The political exclusion of the British working class. Oxford University Press.

Galobardes, Bruna, Mary Shaw, Debbie A. Lawlor, John W. Lynch ja George Davey Smith. 2006. Indicators of socioeconomic position (part 1). Journal of Epidemiology \& Community Health 60:1, 7-12. https://doi.org/10.1136/jech.2004.023531

Galobardes, Bruna, Mary Shaw, Debbie A. Lawlor, John W. Lynch ja George Davey Smith. 2006. Indicators of socioeconomic position (part 2). Journal of epidemiology and community health 60:2, 95-101. https://doi.org/10.1136/jech.2004.028092

Jansen, Giedo, Evans, Geoffrey ja De Graaf, Nan D. 2013. Class voting and left-right party positions: A comparative study of 15 Western democracies, 1960-2005. Social science research 42(2), 376-400. https://doi.org/10.1016/j.ssresearch.2012.09.007

Lahtinen, Hannu. 2019. Socioeconomic differences in electoral participation: insights from the Finnish administrative registers. Publications of the Faculty of Social sciences 125. Helsinki: Unigrafia.

Lahtinen, Hannu, Martikainen, Pekka, Mattila, Mikko, Wass, Hanna ja Rapeli, Lauri. 2019a. Do surveys overestimate or underestimate socioeconomic differences in voter turnout? Evidence from administrative registers. Public Opinion Quarterly 83:2, 363-385. https://doi.org/10.1093/poq/nfz022

Lahtinen, Hannu, Erola, Jani ja Wass, Hanna 2019b. Sibling similarities and the importance of parental socioeconomic position in electoral participation. Social Forces 98:2, 702-724.

https://doi.org/10.1093/sf/soz010

Martikainen, Tuomo ja Sänkiaho, Risto. 1969. Ä̈̈nestysaktiivisuus v. 1968 kunnallisvaaleissa I. Helsingin yliopiston yleisen valtio-opin laitoksen tutkimuksia 16/1969.

Martikainen, Tuomo ja Yrjönen, Risto. 1991. Voting, parties and social change in Finland. Helsinki: Tilastokeskus. 
Tingsten, Herbert. 1937. Political behavior: Studies in election statistics. Stockholm Economic Studies 7. Tukholma: P.A. Norsted \& Söner.

Verba, Sidney, Burns, Nancy ja Schlozman, Kay Lehman. 2003. Unequal at the starting line: Creating participatory inequalities across generations and among groups. The American Sociologist 34:1-2, 45-69. https://doi.org/10.1007/s12108-003-1005-y

\section{KIRJOITTAJATIEDOT}

\section{HANNU LAHTINEN}

VTT, Yliopistonlehtori

Valtiotieteellinen tiedekunta

Helsingin yliopisto

hannu.lahtinen@helsinki.fi 